\title{
Veidenbauma muzealizācija
}

\author{
Iveta Ruskule
}

\section{Kopsavilkums}

Eduarda Veidenbauma kā Latvijas kultūrai unikālas personības apzināšanās sākas tikai pēc viña pāragrās nāves 1892. gadā, kad laikraksta "Dienas Lapa" literārajā pielikumā pirmoreiz nodrukāti pāris Veidenbauma dzejoḷi, bet vēl pēc trim gadiem - 1896. gadā - iznāk pirmais Veidenbauma dzejoḷu krājums "Dzejas". Dzejnieka mantojuma muzealizācija muzeja institūcijas statusā tika sākta 1958. gadā, nodibinot Veidenbauma memoriālo muzeju "Kalāči". Tomēr Kalāču mājas jau daudz agrāk kḷuva par individuālu entuziastu un organizētu grupu apmeklējumu objektu. Pēc dzejnieka nāves šeit turpinās saimniecības ikdiena, bet Veidenbauma dzeju lasošās sabiedrības acīs mājas identitāte ieguvusi jau citu vērtības kodu.

Par svarīgāko eksponātu kḷūst klētiņa, kur vasarās dzejnieks uzturējies, lai apgūtu ǵimnāzijas kursu, lasītu, domātu, rakstītu. Kā rakstīšanas virsmu Veidenbaums izmantojis veḷas rulli. Zīmīgi, ka šì utilitārā, veḷas gludināšanai lietojamā mājsaimniecības rīka muzeālā semantika veidojusies, balstoties tieši Veidenbauma attiecībās ar šo priekšmetu, - apmeklētāji to uztver kā dzejnieka rakstāmgaldu, nevis senu etnogrāfiskas nozīmes artefaktu. Arī pati klētiņa no saimnieciskas ēkas transformējusies muzejiskā eksponātā, kura interpretācija tikai sekundāri pieskaras šìs Kalāču sētā vissenākās celtnes etnogrāfiskajam aspektam. Klētiṇa līdz ar tajā esošo veḷas rulli pirmkārt ir vieta, kurā apmeklētāji tiecas sastapt dzejnieka radošās laboratorijas gaisotni.

Otrais pasaules karš izklīdina Kalāču māju ḷaudis, kā arī izārda šeit koncentrētās atmiņas un priekšmetisko vidi. Ēkas un tajās palikušās lietas zaudē iemantoto muzeālo auru un atgriežas raupjā utilitārā lietojuma vidē: šeit tiek izmitināti Veidenbauma vārdā nosauktā kolhoza strādnieki un iekārtots bērnudārzs.

Muzeja nodibināšana Kalāčos 1958. gada pavasarī kḷūst iespējama, pateicoties Eduarda Veidenbauma māsasmeitas Birutas Leites neatlaidỉbai, vēršoties pie amatpersonām ar aicinājumu saglabāt pirmā latviešu revolucionārā dzejnieka piemiņu. Biruta Leite muzeja veidošanu sāk izpostītā, autentisko auru un lielu dalı muzejisko priekšmetu zaudējušā vidē. Viṇas muzeoloǵiskās izvēles noteicis obligātais ideologiskais konteksts un viņas nostalǵiskā vēlme atjaunot zudušo Kalāču auru. Leite ekspozīciju veido kā subjektīvu atmiņu dokumentu pēc "istabu" principa, radot ar priekšmetiem inscenētu ilustrāciju savām, savas mātes un laikabiedru atmin̄ām par Kalāču vidi. Tā kā no dzejnieka dzīves laika lietiskās patiesības šeit ir palikušas vienīgi sienas un minējumi par atsevišķ lietu autentiskumu, ekspozīcijas memorialitātes sajūtas radīšanai tiek izmantoti dažādas izcelsmes un autentiskuma priekšmeti - no dzimtas iegūti; tipveida interjera priekšmeti; ippaši ekspozīcijai pēc radinieku atmiņu stāstījuma izgatavoti. Tomēr autentiskuma 
mīklas joprojām nav pilnībā atšketinātas tiem dažiem priekšmetiem, kuri muzeja un sabiedrības dialogā tiek iekḷauti kā Eduarda Veidenbauma paša lietoti vai radīti. Eksponētā apalı briḷ̂u pusīte (kuru saglabājis dzejnieka brālēns) un kadiḳa koka spieķis apmeklētāja iztēlē uzbur Veidenbauma vizuālo tēlu, kādu to sabiedrības apziņā nemainīgu nostiprinājusi Tērbatā uzṇemtā fotogrāfija. Ieraugot spieḳi, apmeklētājs to nešaubīgi sasaista ar fotogrāfijā redzamo aksesuāru. Taču, vērīgāk ieskatoties fotogrāfijā redzamajā un eksponētajā aksesuārā, kḷūst skaidrs, ka tie ir divi atšķirīgi priekšmeti.

Fotogrāfijā redzamais spieḳis dzejnieka rokās visdrīzāk nonācis kā uzṇēmuma vizualitātē iederīgs rekvizīts. Savukārt eksponētais pieteikts kā Eduarda Veidenbauma darināts. Šo priekšmetu 20. gadsimta 50. gadu sākumā zem klētiņas atradis kāds Bernhards Krūklis no Liepas ciema Rozēniem.

Tāpat kā Eduarda Veidenbauma dzejas tekstu nonākšana līdz lasītājam caur daudzu pārrakstītāju rokām nesusi līdzi no pirmteksta grūti atsijājamo subjektivitātes klātbūtni, līdzịgi arī dzejnieka piemiņas dokumentēšana un prezentācija muzeja formātā uzkrājusi virkni subjektīvu un par vēlamām pieṇemtu patiesību. Šis daudzo patiesību, leǵendu un detektīva cienīgu meklējumu iespēju kopums ir atslēga uz mūsdienīga un aizraujoša dzejnieka stāsta radīšanu Veidenbauma piemiņas glabātāju rokās.

Raksturvārdi: muzejs, mantojums, Kalāči, klēts, veḷas rullis, spiek̦is, Biruta Leite.

Muzealizācija ir darbība, kas fiziski un semantiski izṇem priekšmetu no tā izcelšanās, dzīves, lietojuma vides, to novietojot muzejā un pakḷaujot tā turpmāko dzīvi muzeja institūcijas likumiem, no vienas, un kuratoru pētniecisko vai radošo ieceru īstenošanai, no otras puses. Līdztekus ievietošanai muzeja vidē, saglabāšanai un dokumentēšanai lietas piedzīvo arī nozīmes maiṇu, jo tās kādā brīdī ir kḷuvušas lielākai sabiedrības daḷai, kopienai vai valstij nozīmīgākas, vērtīgākas nekā ikdienišḳi utilitāri lietojami priekšmeti. Šis process neizbēgami saistās ar interpretācijām un kontekstu meklēšanu. Nemainoties priekšmetu fiziskajam ietvaram un bieži vien arī sākotnējai funkcionalitātei, tomēr veidojas citi attiecību loki starp tiem un sabiedrību, kurai šie priekšmeti kalpo jau kā zīmes, simboli noteiktam naratīvam.

Eduarda Veidenbauma kā Latvijas kultūrai unikālas personības apzināšanās un pieaugošas popularitātes ceḷš sākas tikai pēc vina pāragrās nāves 1892. gadā. Sabiedrība ārpus dzejnieka draugu un līdzgaitnieku loka Veidenbaumu sāk iepazìt pēc gada, kad laikraksta "Dienas Lapa" literārajā pielikumā pirmoreiz nodrukāti pāris Veidenbauma dzejol,i, ${ }^{1}$ bet pirmais drauga Edvarda Treiman,a-Zvārgul,a sakārtotais dzejoḷu krājums "Dzejas” iznāk vēl pēc trim gadiem - 1896. gadā. Dzejnieka dzīvesstāsts un atmiņas par vina personību Treimaņa-Zvārguḷa pierakstā pirmoreiz lasāmas 1907. gadā iznākušajā Veidenbauma Kopotu rakstu pirmajā sējumā. ${ }^{2}$

1 Laikraksta "Dienas Lapa" literārajā pielikumā 1893. gada 22. maijā publicēti Eduarda Veidenbauma dzejoḷi "Pavasarī" un "Ikkatris tev godu dod, centīgais vīrs...".

2 Treimanis-Zvārgulis, E. Eduards Veidenbaums savā dzīvē un darbos. Grām.: Ed. Veidenbauma kopoti raksti. Valmiera: P. Skrastiņš, 1907. 3.-108. lpp. 
Par dzejnieka vizuālo tēlu liecina tikai draugu un laikabiedru atmiṇas, drauga Aleksandra Dauges zīmētais draudzīgais šaržs ${ }^{3}$ un vienīgā zināmā 1890. gadā Tērbatā tapusī fotogrāfija. ${ }^{4}$ Hrestomātisks kḷuvis Veidenbauma sacītais, paužot nevēlēšanos fotografēties: "Kas grib šajā pasaulē ko atstāt, lai atstāj savus darbus." Liktenīgā kārtā šis vēlējums piepildījies arī paša piemiṇas liktenī - tieši darbi aizvien plašāk uzjunda interesi par šā neparasti oriǵginālā dzejnieka personību.

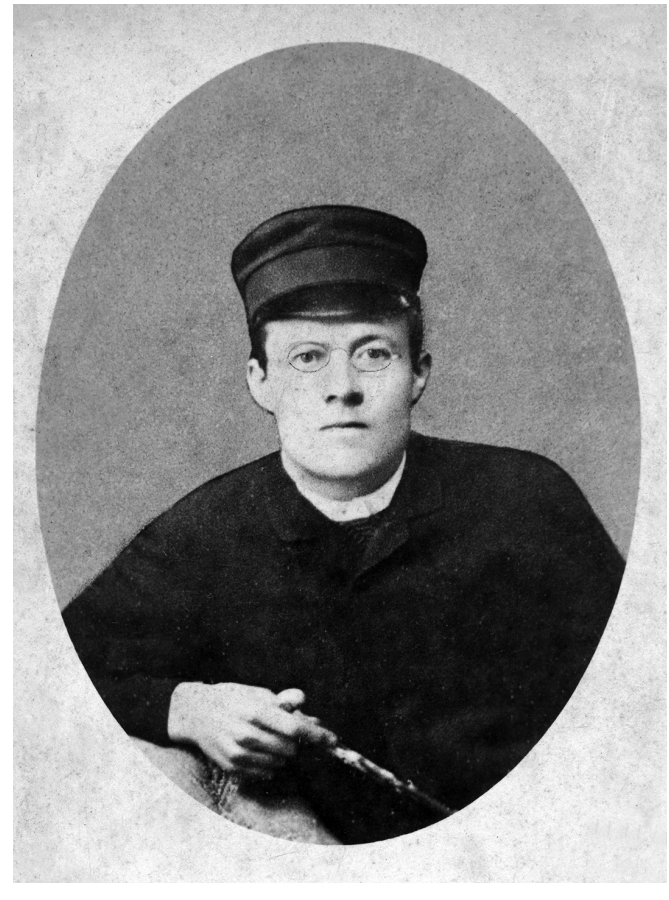

Eduarda Veidenbauma portreta kadrējums no Tërbatas studentu biedrïbas “Pipkolonija” grupas fotogrāfijas Tērbatā 1890 . gada 5. maijā.

Kadrējums: V. Malinovskis. Uzlīmēts uz cietas kartona pamatnes, apakšējā malā dzejnieka autogrāfs.

Rakstniecības un mūzikas muzeja krājums. RTMM, 66046

3 Pirmpublicēts: Ed. Veidenbauma kopoti raksti. Valmiera: P. Skrastiņš, 1907, 72. lpp. kopā ar Aleksandra Dauges atminu pārstāstu. Aleksandrs Dauge šeit arī atminas, ka Eduardu Veidenbaumu karikatūrās zīmējis bieži, tās bijušas izplatītas studiju biedru vidū, bet Dauges rīcībā neviena no tām nav palikusi. Publicētais un līdz mūsu dienām reproducētā formātā saglabājies zīmējums bija nonācis Treimaṇa-Zvārguḷa rokās. Attēls, kā to komentē Treimanis-Zvārgulis, "rāda Veidenbaumu, kas pie $25{ }^{\circ} \mathrm{C}$ saltuma iet pa ceḷu vasaras mētelītī, papirosu zobos iekodis, un lielu platu sarkanu šalli reizes sešas ap kaklu aptinis".

4 Vienīgais neapstrīdami zināmais Eduarda Veidenbauma fotoattēls ir Tērbatas studentu biedrības "Pīpkolonija" grupas fotogrāfija, kas tapusi 1890. gada 5. maijā Tērbatā. Veidenbaums tajā redzams centrā ar spiekii rokās un studenta cepuri galvā. No šìs fotogrāfijas veidoti arī daudzie dzejnieka portreta kadrējumi un reprodukcijas. Kopš 20. gadsimta 80. gadiem tiek uzskatīts, ka eksistē vēl otrs Veidenbauma fotoattēls: kādā neapdzīvotā mājā Rūjienā atrasta fotogrāfija, kurā redzama kāzu viesu grupa Rūjienā. Portretiskā līdzība un dzejnieka biogrāfijā zināmie fakti par mājskolotāja darbu Rūjienā 1890. gadā un viṇa vijoḷspēles prasmi ḷauj pien̦emt, ka jaunais cilvēks grupas pirmajā rindā (ceturtais no labās) ar vijoli rokās patiešām ir Eduards Veidenbaums.

5 Treimanis-Zvārgulis, E. Eduards Veidenbaums savā dzīvē un darbos, 53. lpp. 


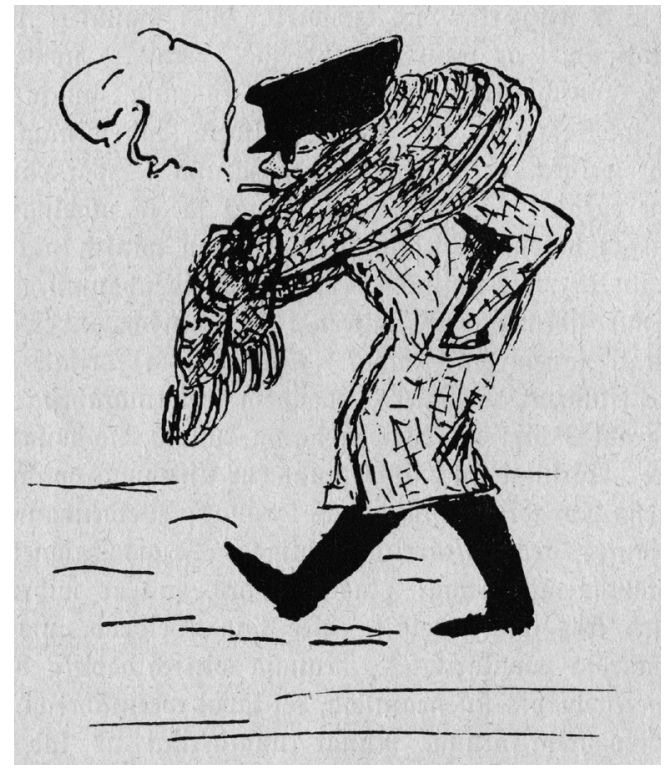

Aleksandrs Dauge. Eduards Veidenbaums.

Reproducēts no: Treimanis-Zvārgulis, E. Eduards Veidenbaums savā dzīvē un darbos. Grām.: Ed. Veidenbauma kopoti raksti. Valmiera: P. Skrastinš, 1907. 72. Ipp.

Lai arī dzejnieka mantojuma muzealizācija muzeja kā institūcijas izpratnē tika īstenota līdz ar lēmuma par Veidenbauma memoriālā muzeja "Kalāči" dibināšanu 1958. gadā, ${ }^{6}$ tās faktiskais sākums iezīmējas jau labu laiku pirms oficiālajiem lēmumiem un ideoloǵiskā uzstādījuma. Par Veidenbauma muzealizācijas centru kḷūst Liepas pagasta Kalāči - mājas, kurās Veidenbaumu ǵimene sāka saimniekot, kad mazajam Eduardam bija pieci gadi. Kalāču mājas kḷūst par dzejnieka pasaules izziņas platformu, radošo laboratoriju. Šeit arī slimības gultā apraujas divdesmit piecus gadus vecā neparasti talantīgā latviešu dzejnieka un domātāja dzīve. Kalāču nozīmi Eduarda Veidenbauma dzìves gājumā un personības attīstībā apliecina arī dzejnieka biogrāfs Rūdolfs Egle:

[Kalāčos] Eduards Veidenbaums uzauga un mācījās pazīt pasauli. Te pavadīta mūža lielākā daḷa. [..] Šinī šaurajā idillē, kurā daudz kas pats par sevi saprotams, [..] Veidenbaums pavadīja to garīgās attīstības posmu, kad prāts vispadevīgāks ārējiem iespaidiem. [..] Kalāčos pavadītais laiks, no apriņ̧̧̧a skolas līdz gímnāzijai, [..] ir vai pats svarīgākais starpbrīdis viṇa gaitās. ${ }^{7}$

Pēc dzejnieka nāves Kalāčos turpinās saimniecības ikdiena.

6 1958. gada 5. novembrī Liepas pagasta "Kalāčos" atklāj Cēsu Novadpētniecības muzeja filiāli, Eduarda Veidenbauma memoriālo muzeju.

7 Egle, R. Eduards Veidenbaums dzìvē un darbos. Cēsis; Rīga: O. Jēpe, 1926, 20., 46. lpp. 


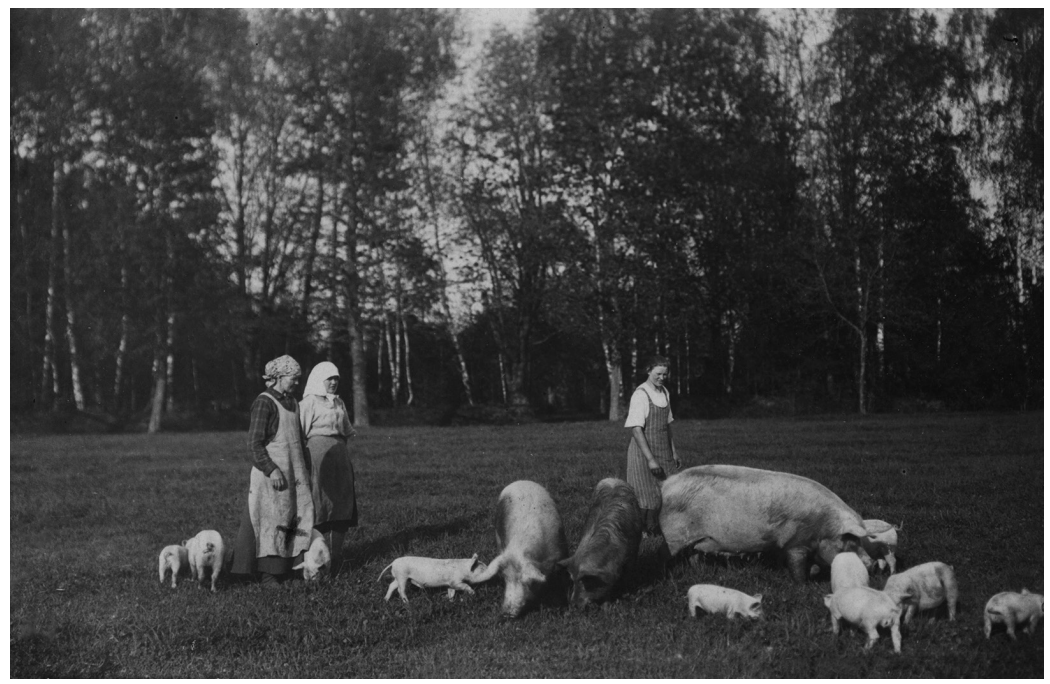

Kalāču saimniece Karlīne Luste, Eduarda Veidenbauma māsa (pirmā no kreisās), un mājas sievas ar cūku ganāmpulku. 30. gadu otrā puse.

Fotogrāfs nezināms [iespējams, Jūlijs Luste].

Rakstniecības un mūzikas muzeja krājums. RTMM, 1519

Tomēr sabiedrības acīs, kas iepazinusi un ciena Veidenbauma daiḷradi, mājas identitāte ieguvusi jau citu vērtības kodu. Kalāči kḷūst par individuālu entuziastu un organizētu grupu apmeklējumu vietu. Kalāču kā muzejmājas vides gida lomu uzṇemas Eduarda Veidenbauma jaunākā māsa Karlīne Luste.

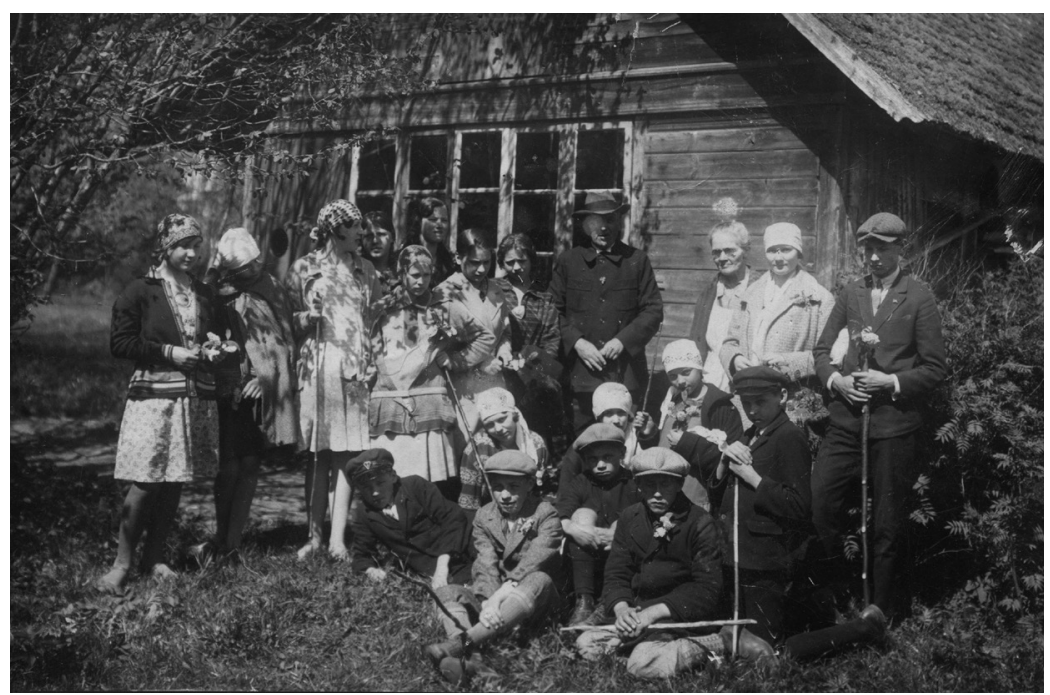

Skolēnu ekskursija Kalāčos, 1928. gads. Centrā skolotājs Kalniṇš, pa labi no viṇa Karlīne Luste. Fotografējis Jūlijs Luste.

Eduarda Veidenbauma memoriālā muzeja "Kalāči" krājums. CMK 1132 
Lai arī apmeklētāji Kalāču mājas ierauga to sadzīves ikdienā, tomēr šīs vietas īpašā uztvere paša nācēja izjūtās apvienojumā ar Karlīnes Lustes teju ar misijas apziņu pavērtajām durvīm uz dzejnieka dzīves un domu telpu šeit pavadīto laiku nenoliedzami pietuvina muzeja apmeklējuma pieredzei:

Pagalmā divas vasarnieces atpūtas krēslos ḷaujas pusdienas saules glāstiem. Prasu, vai šeit Kalāčos dzīvo vēl kāds Veidenbauma radinieks? Jā, viņa māsa! Tūlin, pasaukšu...

Drīz iznāk meklētā - Eduarda māsa, ap septiņdesmit gadu veca, bet loti žirgta vecìte. Zilpelēkās acis laipni raugās manī, un klusā balss aicina mani iekšā atpūsties. Viña cienā mani ar raudzētu bērzsulu, kas patīkami veldzē un atspirdzina. Runājam par Eduardu, un viṇa māsa stāsta man savas atmiņas. ${ }^{8}$

Kalāčos kā dzejnieka piemiņas vietā iegriežas arī augstas valsts amatpersonas. 1932. gadā tiek plaši atzīmēta Eduarda Veidenbauma nāves četrdesmitā gadadiena, un tās sakarā Kalāčos viesojas Saeimas priekšsēdētājs Pauls Kalniņš, aktrise Paula Baltābola, Ministru prezidenta adjutants Miervaldis Lūkins.

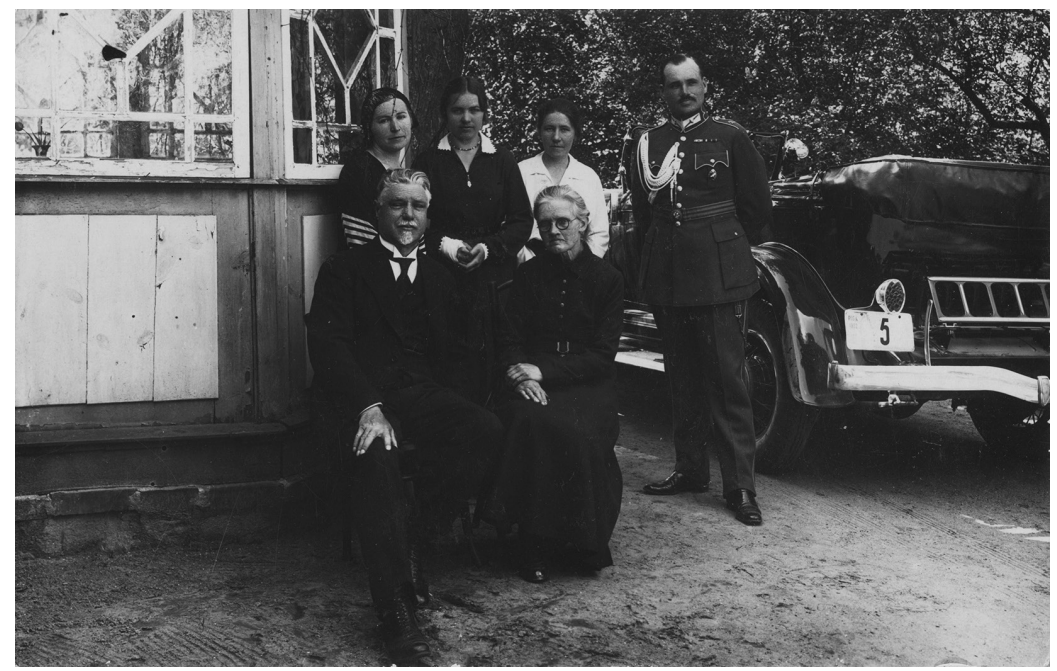

Valsts amatpersonu apciemojums Kalāčos sakarā ar Eduarda Veidenbauma četrdesmitās nāves gadadienas piemiṇas pasākumu Liepas kapsētā 1932. gada 29. maijā. Pirmajā rindā no kreisās: 1. Saeimas priekšsēdētājs Pauls Kalniṇš, 2. Eduarda Veidenbauma māsa Karlīne Luste. Otrajā rindā no kreisās: 1. aktrise Paula Baltābola, 2. Biruta Luste, Karlīnes meita, 3. Anna Rodziṇa, 4. Ministru prezidenta adjutants Miervaldis Lūkins. Fotogrāfs nezināms.

Rakstniecības un mūzikas muzeja krājums. RTMM, 1557(1)

8 Vētra, U. Veidenbauma dzīves vietā - Mūrmuižas Kalāčos. Latvijas Kareivis, 1938, Nr. 288, 18. dec. 
Jau tad, Kalāču neformālās muzejmājas dzīves laikā, par svarīgāko dzīvo eksponātu kḷūst klētiṇa.

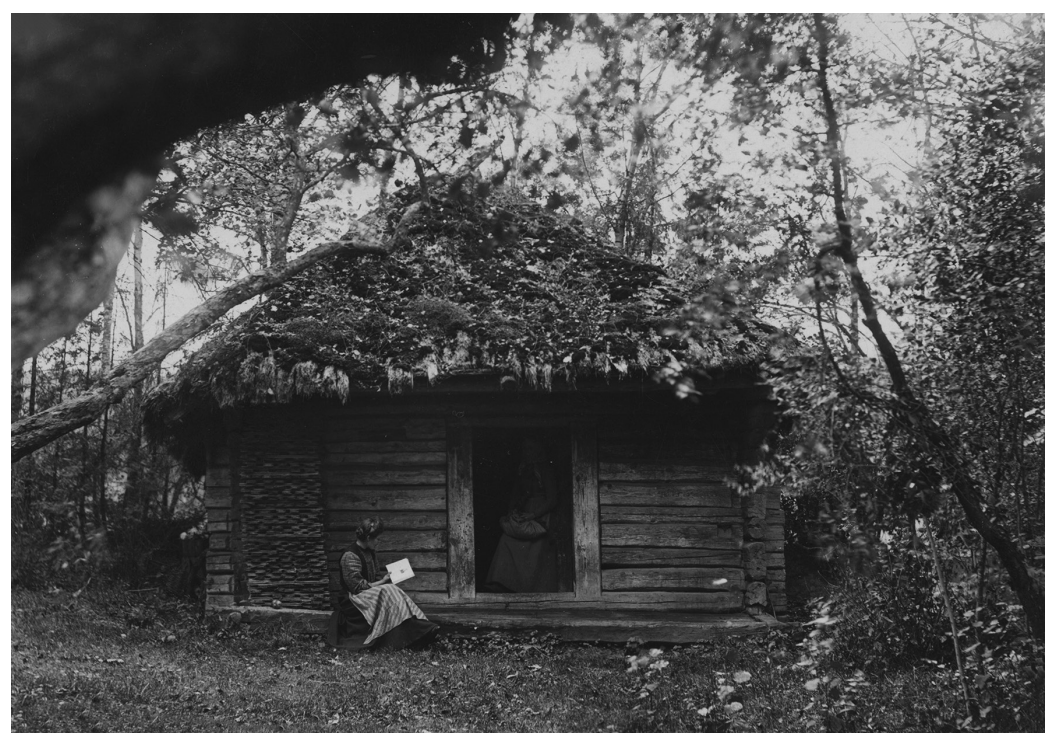

Kalāču klētiṇa ap 1912. gadu.

Fotografējis Jūlijs Luste.

Rakstniecības un mūzikas muzeja krājums. RTMM, 758

Arī tā joprojām tika izmantota saimniecības vajadzībām, bet vienlaikus tās durvis tika vērtas apmeklētājiem, laujot sajust Veidenbauma "studiju salona" auru. Saimniecības ikdienā praktiskam mērḳim kalpojušo ēku, pēc māsas Karlīnes atmiņām, Veidenbaums gada siltajos mēnešos labprāt izmantojis kā klusu vietu, kur netraucētam apgūt ǵimnāzijas kursu, gatavoties eksāmeniem, lasīt, domāt, rakstìt. Klētiņas kā Veidenbauma garīgās dzìves centra identitāti apcerē "Eduards Veidenbaums dzīvē un darbos" īpaši uzsver Rūdolfs Egle. No klētiṇā esošā saimnieciskā inventāra autors piemin tikai tos priekšmetus, kuri bijuši būtiski dzejnieka uzturēšanās un darba videi šajā telpā:

Klētin̄ā atradās gulta ar vienkāršu salmu maisu, krēsls un turpat blakus veḷas rullis. Šai idilliskajā miteklī ar apsūnojušu salmu jumtu, augstu slieksni un vecmodīgām aizbultējamām durvīm uzrakstīts Veidenbauma dzeju lielais vairums, remdētas "zinību slāpes" un pārlaistas trauksmainās pārdomas par cilvēces likten,iem. Rakstīja viṇš pārliecies uz vel̦as ruḷ,a, uz kura novietotas atradās grāmatas, burtnīcas, tinte un spalva. Šāds vienkāršs oriğināls rakstāmgalds gan laikam nebūs bijis nevienam rakstniekam. ${ }^{9}$

9 Egle, R. Eduards Veidenbaums dzìvē un darbos, 44.-45. lpp. 


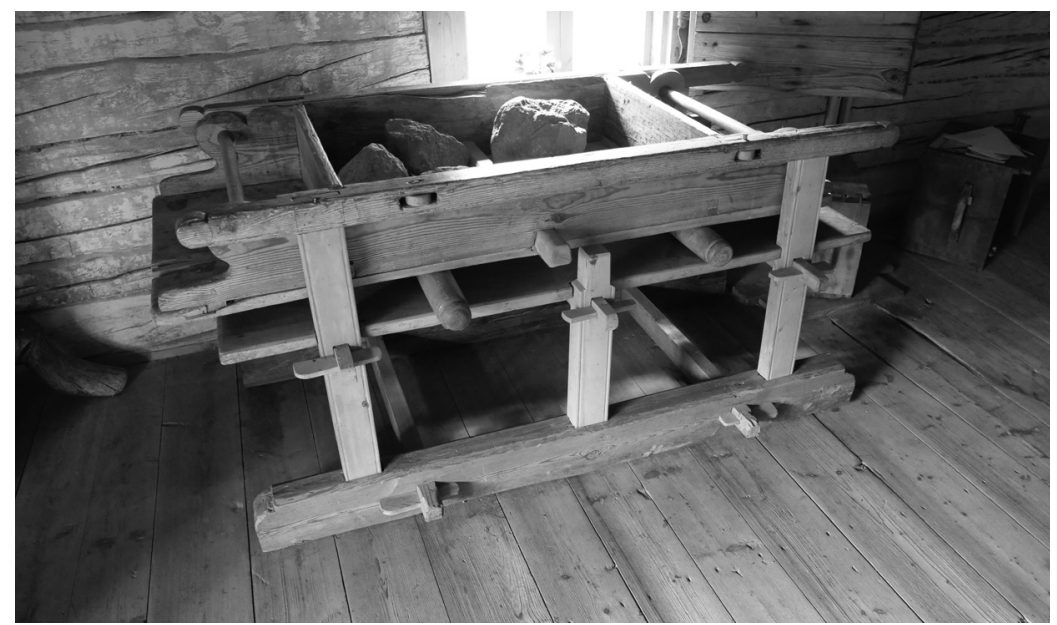

Veḷas rullis Kalāču klētiṇā.

Fotografējis Roberts Skrajāns

Zīmīgi, ka šì saimniecībā visnotal, utilitārā, veḷas gludināšanai lietojamā mājsaimniecības rīka muzeālā semantika jau tolaik veidojusies, balstoties tieši Veidenbauma attiecībās ar šo priekšmetu, - apmeklētāji to uzlūko kā dzejnieka rakstāmgaldu, nevis veḷas rulli, kuru kā tādu aicina izzināt etnogrāfiskas ievirzes muzeji.

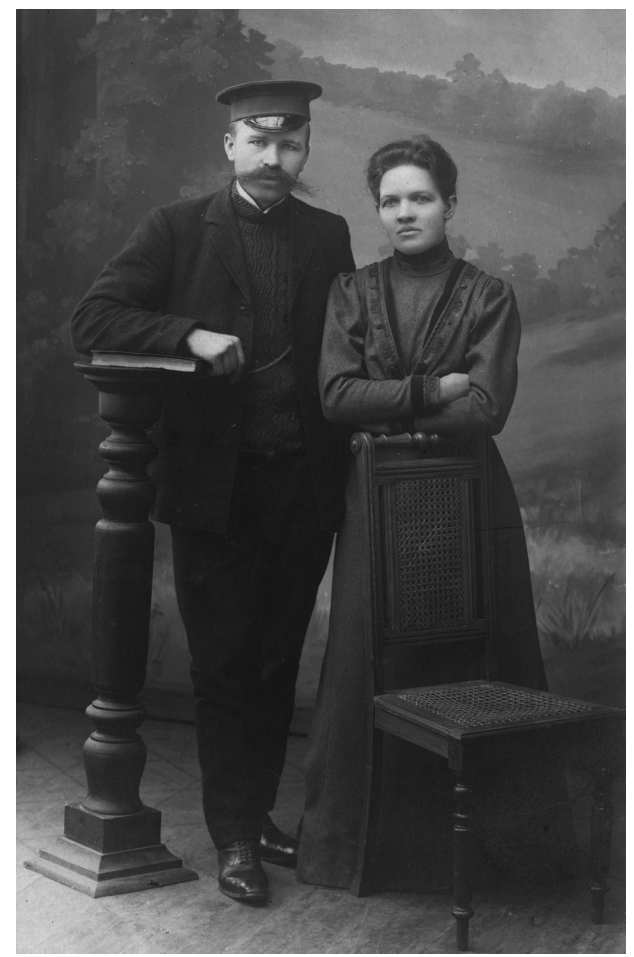

Eduarda Veidenbauma jaunākā māsa Karline Luste ar dzivesbiedru Jūliju Lusti ap 1910. gadu.

Salona foto, fotogrāfs nezināms.

Rakstniecības un mūzikas muzeja krājums RTMM, 68999 
Īpašs muzealizācijas stāsts ir pašam Veidenbauma "studiju salonam" - klētiñai. No saimnieciskas ēkas, kurā tiek glabāta ābolu raža un kur no mājas rosības savu radošo patvērumu atradis Veidenbaums, tā transformējusies muzejiskā eksponātā, kura vēstijums un interpretācija tikai sekundāri pieskaras šīs Kalāču saimniecībā vissenākās ēkas etnogrāfiskajam aspektam. Klētiņa līdz ar tajā esošo velas rulli, kuru Veidenbaums izmanto rakstāmgalda vietā, pirmām kārtām ir vieta, kurā apmeklētāji tiecas sastapt dzejnieka radošās laboratorijas gaisotni. Tā ir arī viens no visrūpīgāk dokumentētajiem objektiem Veidenbauma piemiñas stāsta priekšmetiskajā vidē. Izsekojams un aizraujošs ir tā dokumentēšanas stāsts, kas iezīmē divus kardināli atškirirgus attiecību modeḷus ar šo objektu un divas izpratnes par Veidenbauma piemiņas saglabāšanu. Klētiņas transformāciju par piemiñas vietu aizsācis Veidenbauma māsas Karlīnes vīrs Jūlijs Luste.

Būdams fotogrāfs un Veidenbauma daiḷrades cienìtājs, viņš pirmais veicis tās fotofiksāciju. Viṇa 1910. gadā uzṇemtajā klētinas attēlā jau redzams ēkas bēdīgais fiziskais stāvoklis.

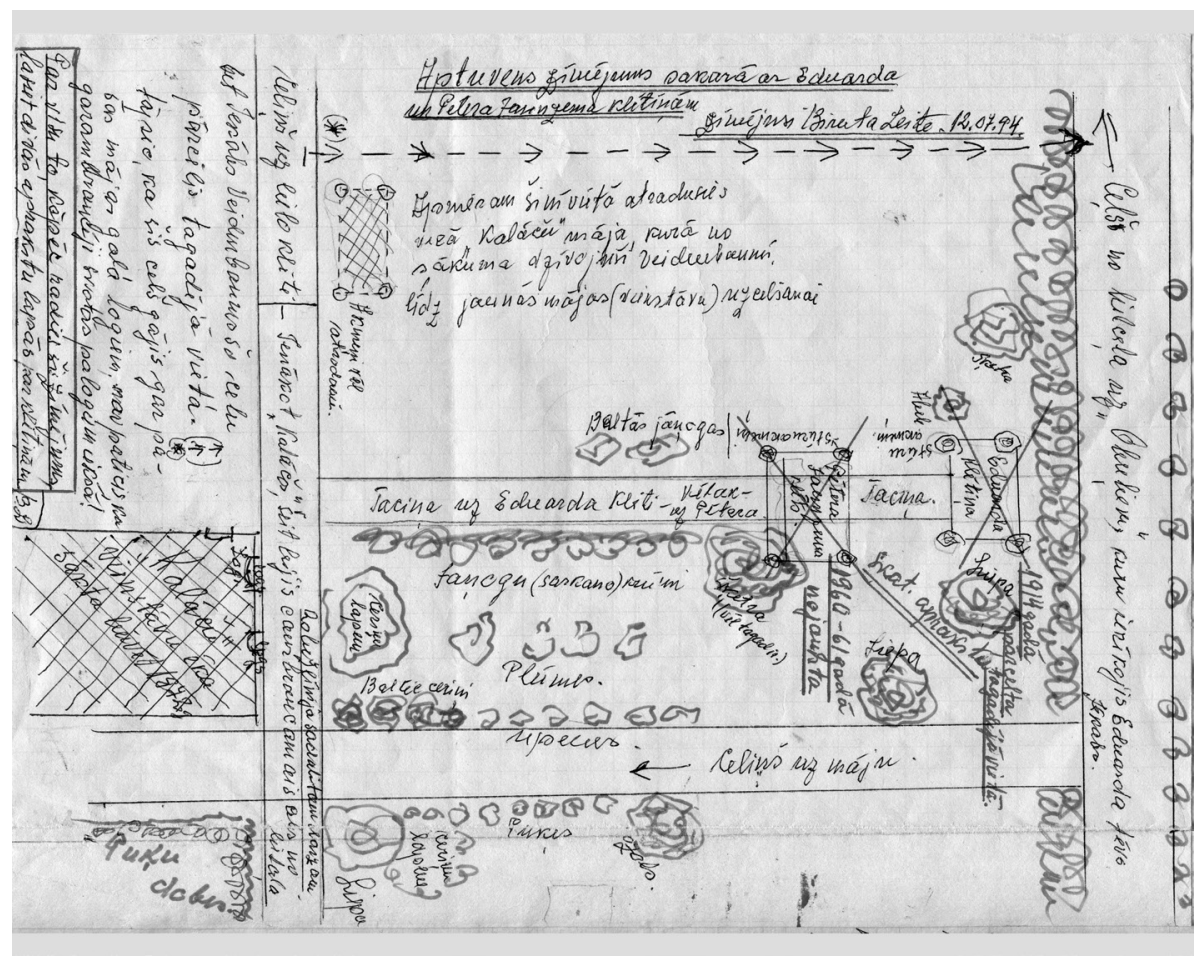

Birutas Leites zīmējums ar Kalāču dārza plānu un klētiṇas sākotnējo novietojumu lĩdz tās pārcelšanai uz jauno vietu 1914. gadā. lezīmēta arī pēc Pētera Jaunzemītes pieprasījuma uzceltā jaunā klēts, kas 1960. gadā nojaukta. Zīmējums pievienots Leites atmiṇām "Par Kalāčiem un klētiṇām", Liepā, 1994. gada 12. jūlijā, 5. Ip.

Eduarda Veidenbauma memoriālā muzeja "Kalāči" arhīva materiāls 
Kad apprecas otra māsa Jūla Veidenbauma, Kalāču dārzs tiek sadalīts divās daḷās, un klētiṇa paliek māsas un vinas vīra Pētera Jaunzemītes pusē. Pētera redzējumā laika zoba stipri skartajai būvei l,aujams dabiskais sabrukšanas liktenis, bet Jūlijs Luste piedāvā to nojaukt un pārcelt savā un Karlīnes dārza daḷā. Pēc vairākkārtējas uzrunāšanas Pēteris piekāpjas, bet vietā pieprasa uzcelt jaunu klētiņu. Lai saglabātu Veidenbauma lietotās klētiṇas veidolu nemainītu, Jūlijs Luste 1914. gadā gandrīz vai ar etnogrāfa rūpību pirms nojaukšanas rūpīgi numurē katru balk, i, lai pēc pārcelšanas uz savu dārza daḷu to novietotu autentiskā izkārtojumā.

Lìdz pat 1960. gadam Kalāčos var redzēt veselas divas klētiņas. 1960. gadā, labiekārtojot muzeja teritoriju, Pētera klētiņa nojaukta, atstājot vietu apmeklētāju transporta novietošanai, bet Veidenbauma "studiju salonu" restaurēja Brīvdabas muzejā.

Otrais pasaules karš ne tikai izklīdina Kalāču māju ḷaudis, bet līdz ar tiem izārda šeit koncentrētās atmiņas un priekšmetisko vidi. Karlīnes meitu Birutu Leiti 1941. gadā deportē uz Sibīriju, 1943. gadā mirst Karlīne, bet Jūlijs Luste 1944. gadā dodas emigrācijā. Ēkas un tajās palikušās lietas zaudē iemantoto muzeālo auru un atgriežas raupjā utilitārā lietojuma vidē. Kalāču istabās tiek izmitināti Veidenbauma vārdā nosauktā kolhoza strādnieki un iekārtots bērnudārzs. Formāli kolhozam uzdots rūpēties par Kalāču ēku kā "progresīvā dzejnieka" Eduarda Veidenbauma dzīves un darba vietu, taču tas nenotiek pat formāli Kalāču uztveres pārmantojamības pārrautā nabassaite nav ar formāliem rīkojumiem sasienama. Lai konstatētu situāciju, 1956. gada 15. un 16. aprīlī Kalāčos ierodas komisija, kurā ietilpst toreizējā Cēsu rajona amatpersonas, Valsts Vēstures muzeja darbinieki, Cēsu Novadpētniecības muzeja direktore Ozola. Komisijas sastādītajā aktā situācija Kalāčos raksturota šādi:

Konstatēta bezatbildīga pieeja un vistiešāko ar dzejnieka dzīvi saistīto vēl atlikušo priekšmetu postǐšana: atremontējot dzīvojamo ēku, nojaukta veranda, un tās stikla logi tagad salikti gan kūtīm, gan pagrabiem. Telpā, kur miris dzejnieks, iemūrēta mūra plīts, klētinai izsisti logi, jumts caurs, telpā ieplūst ūdens. No klētinas jau pagājušajā rudenī izmesti ārā veḷas rullis un pults atliekas, stāv sniegā un ūdenī. ${ }^{10}$

Divkārt Sibīrijas nometnēs pabijušās Eduarda Veidenbauma māsasmeitas Birutas Leites neatlaidīgā klauvēšana pie daudzo amatpersonu durvīm, uzstājīga apelēšana pie viṇu sirdsapziṇas ar Veidenbauma kā pirmā latviešu revolucionārā dzejnieka piemiņas saglabāšanas nepieciešamību pārliecina tiktāl, ka 1958. gada pavasarī tiek izdots Latvijas PSR Ministru Padomes lēmums, ka Liepas ciema Kalāčos iekārtojams dzejnieka memoriālais muzejs.

${ }^{10}$ Akts komisijas dalībnieces, toreizējās Raing Literatūras un mākslas vēstures muzeja darbinieces Edītes Kazaines norakstā. Rakstniecības un mūzikas muzeja krājums. RTMM, 553448. 


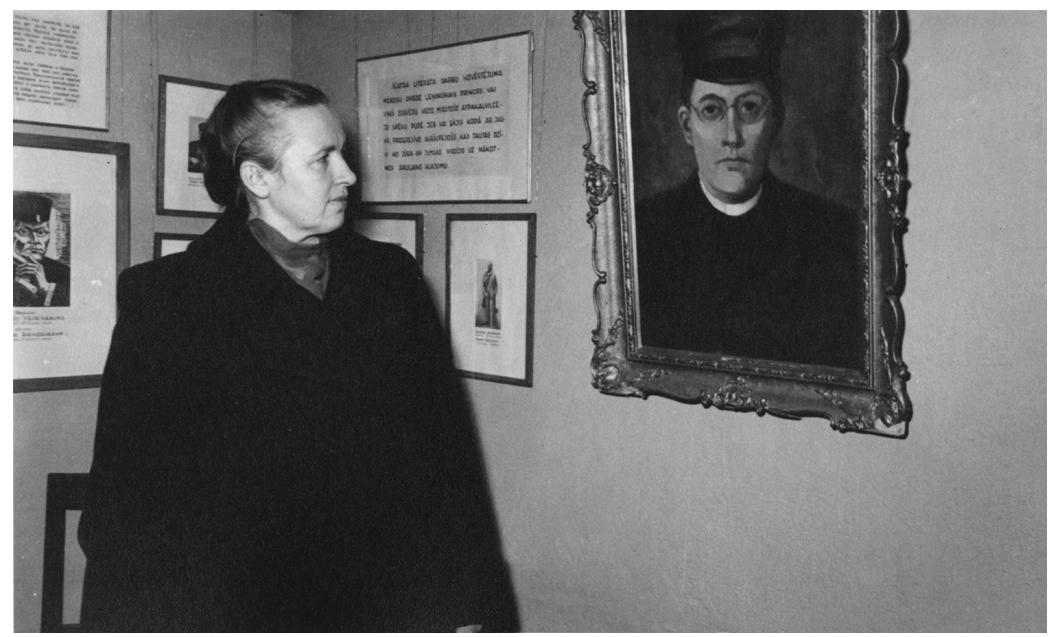

Biruta Leite Eduarda Veidenbauma memoriālā muzeja ekspozīcijas atklāšanas dienā 1958. gada 13. novembrī. Fotogrāfs nezināms.

Rakstniecības un mūzikas muzeja krājums. RTMM, 75839

Ekspozīciju atver 1958. gadā, bet Leites izstrādātais ekspozīcijas plāns liecina, ka līdz pat 1975. gadam tā tiek papildināta un pilnveidota ar jauniegūtiem priekšmetiem. ${ }^{11}$ Nosacīti memoriālajā vidē ienāk arī inscenējuma sajūtu pastiprinoši priekšmeti - Veidenbauma portretējumi mākslā, ${ }^{12}$ ar dzejnieka biogrāfiju saistītu vietu fotoattēli. Arī ekspozīcijas satura vēstījumam nav stingri sazīmējamu laika robežu. Muzeja vēstījumā un atsevišksu priekšmetu interpretācijā gan neizbēgamas ir nodevas Veidenbauma kā "revolucionārā dzejnieka" stāstam. Nav izdevies uzmeklēt tā laika muzeja misijas aprakstu, bet uzstādījuma skaidrībai pietiek ar ekspozīcijas ievada zālē izvietoto tekstu:

${ }^{11}$ Būtiskākie papildinājumi ir viesu istabas ekspozīcijā 1960. gada rudenī eksponētais tikko kā iegūtais atradums zem Kalāču klētiṇas - Veidenbauma itin kā pašrocīgi darinātais spiekis, bet 1962. gadā ēdamistabas ekspozīcijā novietota pēc Veidenbauma māsas vīra Jūlija Lustes un meitas Birutas Leites apraksta Cēsu mēbeḷu cehā izgatavotā rakstāmpults. Vairums papildinājumu ir saistīti ar muzeja darbību un Veidenbauma popularitātes pieaugumu - lielākā daļa dzejnieka portretējumu, dažādi dāvinājumi, piemēram, priekšnamā novietotā ekskursantu dāvinātā māla vāzīte un kādas Rīgas arodskolas audzēkṇu darinātais metāla svečturis, viesu istabā vieta atrasta arī māla vāzei, kuru muzeja divdesmit gadu jubilejā dāvinājis Eduarda Veidenbauma kolhozs.

${ }^{12}$ Birutas Leites ekspozīcijas plānā fiksēti seši dzejnieka portretējumi, kuri tapuši laikposmā no 50. gadu otrās puses līdz 70. gadu beigām, un noprotams, ka arī ekspozīcijā izvietoti pakāpeniski - laika gaitā. Dažādās tehnikās - monotipija, zīmējums ar zīmuli, ellıas glezna, vitrāža, ǵipša biste - veidotie dzejnieka portretējumi eksponēti verandas un priekšnama telpās. Autori: Vitolds Svirskis, Arturs Dronis, Fricis Ešmits, Tenis Grasis, Zenta Muceniece un kāds nenoskaidrots sanatorijas "Cēsis" pacients. 
Katra literāta darbu novērtējuma mērogu sniedz l,eņiniskais princips, vai viņš stāvējis veco mirstošo atpakalvilcēju spēku pusē jeb vai gājis kopā ar jauno, progresivvo augšupejošo, kas tautas dzīvi no jūga un tumsas virzījis uz nākotnes saulaino klajumu. ${ }^{13}$

Ekspozīcijas atvēršana un tās ideologiskais ietvars izraisa viedokḷu sadursmi abpus Padomju Savienības robežām. Ar dažu dienu starpību divos izdevumos parādās publikācijas, kurās Veidenbauma mantojuma interpretācija jaunatvērtajā muzejā sajūsmina un sanikno. "Vēl pilnīgi nav restaurēta klētiņa, bet tur redzam veḷas rulli, uz kura dzejnieks rakstījis savas mūžam dzīvās rindas: "Mosties, mosties reiz, svabadais gars; Celies un salauzi tumsības spaidus","14 raksta oficiālais laikraksts "Cīṇa". Savukārt publikācijā "Londonas Avīzē" pausts sašutums:

Komunisti, turēdami verdzībā visu latviešu tautu, vēlas savāžot arī mirušos dzejniekus, piesaistot tos sev, kaut gan Veidenbaums nekad nav bijis marksists. Turklāt jāpiezīmē, ka Veidenbauma ǵimenes atvases ir deportētas uz Sibīriju. ${ }^{15}$

Biruta Leite muzeja veidošanu sāk izpostītā, autentisko auru un lielu daḷu muzejisko priekšmetu zaudējušā vidē. Ieskatoties rūpīgi dokumentētajā ekspozīcijas plānā, atminu pierakstos un pieejamajās fotogrāfijās, redzams, ka Birutas Leites muzeolog̣iskās izvēles noteicis jau minētais obligātais ideoloǵiskais konteksts un viņas nostalğiskā vēlme atjaunot zudušo Kalāču auru. ${ }^{16}$ Leite ekspozīciju veido kā subjektīvu atmiņu dokumentu pēc “istabu” principa, radot ar priekšmetiem inscenētu ilustrāciju savām, savas mātes un laikabiedru atmin̄ām par Kalāču vidi. Katrā no istabām - veranda, priekšnams, ēdamistaba, māsu istaba, viesu istaba (zāle), mātes istaba, steḷlu istaba, virtuve, rentnieku istaba, klētin, pirtiņa - izvietots anotācijas teksts par tās lietojumu mājinieku sadzīvē, iezīmējot arī Veidenbauma biogrāfiskās attiecības ar atsevišḳām telpām un tajās izvietotajiem priekšmetiem. ${ }^{17}$

${ }^{13}$ Teksts bez avota norādes stiklotā planšetē novietots pie sienas Birutas Leites veidotās ekspozīcijas sākumā (verandā) līdzās Vitolda Svirska monotipijas tehnikā veidotajam Eduarda Veidenbauma portretējumam (skat. attēlu 141. lpp.).

${ }^{14}$ Priede, P. Eduarda Veidenbauma "Kalāčos". Cīna, 1958, Nr. 266, 12. nov.

${ }^{15}$ Veidenbauma mūzejs Kalačos. Londonas Avizze, 1958, Nr. 651, 28. nov.

${ }^{16}$ Biruta Leite, Eduarda Veidenbauma māsas Karlīnes Lustes meita, līdz izsūtījumam uz Sibīriju (1941) piedzīvoja pirmskara neizpostītos Kalāčus, kur mājinieku vidē tika uzturētas dzīvas atminas par dzejnieka klātbūtni viņa dzīves laikā.

${ }^{17}$ Tā, piemēram, viesu istabā ("zālē") eksponētais šūpuḷkrēsls ar niedru sloksnīšu pinumu ekspozīcijas plānā minēts kā Veidenbaumu ǵimenei piederošs, kurā Veidenbaums slimības laikā sēdējis "sarkanām samta tupelītēm kājās". 
Priekšmetu iegūšanas avoti izsekojami pēc ekspozīcijas plāna, ${ }^{18}$ kā arī pēc Birutas un laikabiedru atmiṇām. ${ }^{19}$ Apstākḷos, kad no dzejnieka dzivves laika lietiskās patiesības šeit ir palikušas vienīgi sienas un minējumi par atsevišķu lietu autentiskumu, ekspozīcijas inscenējumos memorialitātes šķituma radīšanai tiek kopā likti dažādas izcelsmes un autentiskuma priekšmeti - dzimtai piederīgo atvēlētie (ēdamgalds), tipveida interjera priekšmeti, ko muzejam dāvinājuši apkaimes iedzìvotāji (tamborēts galdauts) vai kas aizṇemti no Cēsu Vēstures un mākslas muzeja (galda lampa ar kupolu), pēc radinieku atmiṇu stāstījuma izgatavotie (rakstāmpults, izgatavota Cēsu mēbeḷu cehā 1962. gadā pēc Jūlija Lustes un Birutas Leites liecībām). Savukārt tintnīca, kas ekspozīcijā iekḷauta kā "memoriāla" Eduardam Veidenbaumam piederējusi lieta, patiesībā bijusi brāla Kārḷa īpašums, kuru viņš ieguvis jau pēc Eduarda nāves.

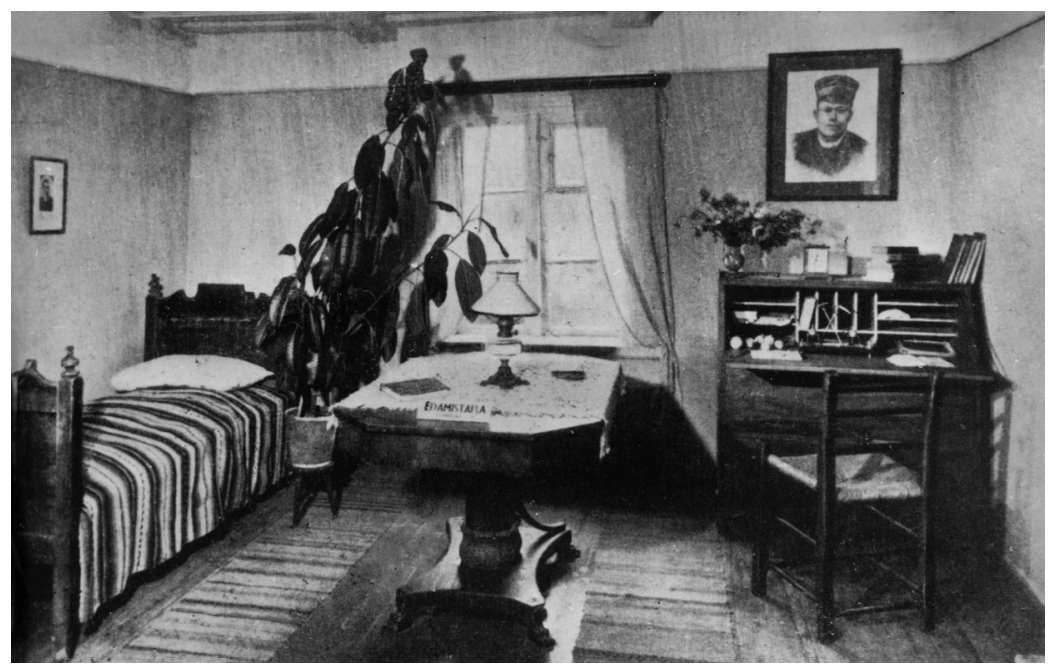

Ėdamistabas interjers Birutas Leites veidotajā ekspozīcijā Kalāčos.

Fotokopija no: Anspaks, A. Eduards Veidenbaums. Cēsis, 1970. Neg. KPRPK

(Kultūras pieminekḷ restaurēšanas projektēšanas kantoris) fotoarh. Nr. 38590

${ }^{18}$ Cēsu Vēstures un mākslas muzeja filiāles "Eduarda Veidenbauma memoriālā muzeja "Kalāči"” tematiskais ekspozīcijas plāns. Sastādījusi muzeja vadītāja Biruta Leite. [1975. g.], 49 lp. Eduarda Veidenbauma memoriālā muzeja "Kalāči" arhīvs.

${ }^{19}$ Atmiņu avoti: 1) Birutas Leites sastādīts saraksts "Priekšmeti, kas bijuši "Kalāču" istabās un klētin̄ā E. Veidenbauma dzīves laikā. Pēc Karlīnes Lustes, dz. Veidenbaumas, E. Veidenbauma jaunākās māsas, apliecinājuma Kalāčos, 1979. gada 4. oktobrī”, 2 lp. Eduarda Veidenbauma memoriālā muzeja "Kalāči" arhīva materiāls; 2) Birutas Leites atmiņas "Par "Kalāčiem" un klētin̄ām", Liepā, 1994. gada 12. jūlijā, 5 lp. Eduarda Veidenbauma memoriālā muzeja "Kalāči" arhīva materiāls; 3) Raiṇa Literatūras un mākslas vēstures muzeja darbinieces Edītes Kazaines apkopotie materiāli par E. Veidenbauma memoriālā muzeja "Kalāčos" iekārtošanu. Rakstniecības un mūzikas muzeja krājums, RTMM, 500068; RTMM, 553448; 4) Jugāne, V. Par tiem, ko atceras "Kalāčos". Dzimtenes Balss, 1967, Nr. 41, 8. okt. 
Birutas Leites muzejnieciskā degsme Kalāču lietiskajai videi atdot zaudēto izpaužas arī visnotal azartiskos muzeja priekšmetu medību piedzīvojumos. No mātes stāstiem atmin̄ā subjektīvi dokumentētās kādreiz Kalāču istabās un saimniecības ēkās esošās lietas, ja vien juku laikos nav gājušas bojā, domājams, tepat apkārtnes mājās varētu būt atrodamas. Vienā no tādām ekspedīcijām tiek uzmeklēta un muzejā nogādāta sena pūra lāde. Birutas Leites pārliecība par tās autentisko saikni ar Kalāčiem ir tik spēcīga, ka neattur viņu no kāda pārgalvīga darījuma nakts aizsegā:

Tikko apsēto lauku un pavasara ziedu kupenu reibinošā smarža saplūst ar lakstīgalu trellıiem. Nakts. Bēris mierīgi skaita soḷus. Birutas Leites un vin,as līdzbraucēju ceḷa mērḳis ir gaužām romantisks. Tā ir sēta, kur dzīvo attāli Veidenbauma radinieki. [..] vecā māmiṇa tur glabā savu jaunības pūra lādi. Biruta Leite jau sensenis ir lūgusies, lai šo lādi atdod muzejam; tieši tāda kādreiz stāvējusi arī Kalāču klētiņā blakus Veidenbauma iemīlotajam "rakstāmgaldam" - veḷas rullim - un gultiņai. Bet 86 gadus vecā vecenīte nevēlas, ka viṇas lāde aizceḷotu no mājām. Tagad mājas saimniece saka - ja nesteigšoties, no lādes nekas pāri nepalikšot. Lai taču esot gudri, atbraucot naktī un aizvedot. Viņa klētiņu neaizslēgšot... Un tā nakts aizsegā lēni un uzmanīgi, uz pirkstu galiem klētī ieiet Biruta Leite, seko viņas vīrs, dēls un kāda l,oti enerğiska ekskursante, kas "Kalāčos" palikusi pārnakšņot un no tik romantiskas dēkas nav gribējusi atteikties. Četri sazvērnieki piekeras katrs pie sava lādes stūra. Suṇi rej. [..] Un tad sākas atceḷš. Atkal lakstīgalas, vieglais pavasara vējiņš un nebēdnīgi smiekli. Romantiskais piedzīvojums beidzies ar uzvaru. Lāde izglābta, muzejam iegūts jauns vērtīgs eksponāts. Vēl tikai jāpiebilst, ka vecmāmuḷa tā arī nomirusi, nezinādama, ka viṇas lāde atradusi citas mājas, kur reizēm bijīga roka viegli noglāsta tās nomelnējušos sānus. ${ }^{20}$

Autentiskuma mīklas joprojām nav pilnībā atšḳetinātas arī saistībā ar tiem skaitā nedaudzajiem priekšmetiem, kuri muzeja un sabiedrības dialogu visciešāk satuvina ar Eduardu Veidenbaumu, - tos lietojis vai radījis dzejnieks. Veidenbauma reiz sacītais par to, ka pasaulē atstāšanas vērti ir vienīgi cilvēka darbi, spītīgā pieticībā attiecas arī uz šo - ar vina personību saistāmo priekšmetisko mantojumu. Taču vēlme ieraudzīt priekšmetu, kas reiz piederējis leǵendārajam dzejniekam, ir memoriāla muzeja apmeklētāja viena no primārajām gaidām. Arī paša muzeja pašapziņa nereti vairāk saistās ar kolekcijas unikalitāti un memoriālo vērtību nekā ar tās padziḷinātas izpētes un interpretācijas spēju unikāla vēstījuma kontekstā. Šajā gaidu un pašapziņas satikšanās teritorijā mēdz rasties arī mìti, un memorialitātes gars iemājo pat priekšmetos, kuru fiziskā piederība un emocionālā saikne ar leǵendāro personu ne vienmēr ir tik patiesa, kādu to vēlas izstāstìt vieni un kādai noticēt ir gatavi otri.

${ }^{20}$ Jugāne, V. Par tiem, ko atceras "Kalāčos". 
Kurš no populārākajiem Veidenbaumam piedēvētajiem priekšmetiem patiešām glabā šo svēto saikni ar dzejnieka ìso dzīves sprīdi, bet kurš šo saikni ieguvis iztēlē un noticēšanā tai? Kalāčos eksponētā apaḷo briḷ,u pusīte un kadiḳa koka spieķis apmeklētāja iztēlē uzbur Veidenbauma vizuālo tēlu, kuru sabiedrības apziṇā nemainīgu nostiprinājusi Tērbatā uzṇemtā fotogrāfija. Gluži kā Eduarda Veidenbauma brālēna Kārḷa Hincenberga saglabātā briḷı pusīte, arī šo ar pietāti uzlūkoto priekšmetu memoriālā patiesība ir puspatiesība un tomēr - šarmanta savā noslēpumainībā.

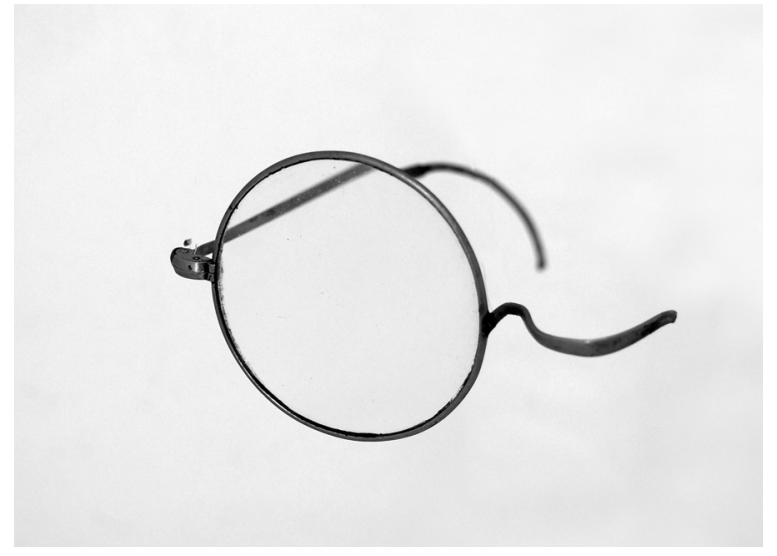

Brịl|u pusīte, kuru saglabājis un Eduarda Veidenbauma muzejam dāvinājis Eduarda Veidenbauma brālēns Kārlis Hincenbergs.

Fotografējis Roberts Skrajāns. Eduarda Veidenbauma memoriālā muzeja "Kalāči" krājums. CMK 2057

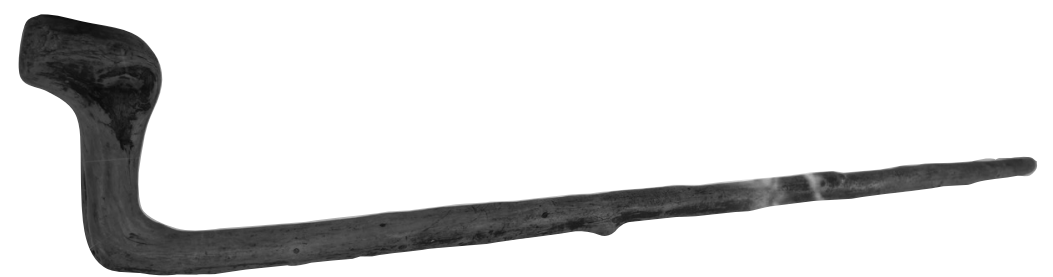

Kadiḳa koka spieḳis, atrasts zem Kalāču klētiṇas 20. gs. 50. gados.

Fotografējis Roberts Skrajāns.

Eduarda Veidenbauma memoriālā muzeja "Kalāči" krājums. CMK 92

Nespējot atsaukt atpakal, brīdi, kad priekšmeti no radinieku atmiṇu un pašsaprotamās zināšanas par to piederību dzejniekam nokḷūst muzeja jau kā plašai sabiedrībai un nākamībai kalpojošas institūcijas valdījumā, priekšmeti šeit spēlē detektīva cienīgu spēli. Brīžiem tie tveras leǵendas ērtajā paspārnē, brīžiem vedina pietuvoties vēsturiskās patiesības izzināšanas azartam. Vienā gadījumā, ieraugot vitrīnā guldīto spiekị, apmeklētājs to nešaubīgi sasaista ar fotogrāfijā redzamo aksesuāru. Otrā gadījumā, vērīgāk ieskatoties fotogrāfijā redzamajā un 
eksponētajā aksesuārā, kḷūst skaidrs, ka tie ir divi atšķirīgi priekšmeti. Fotogrāfijā redzamais spiekis, Veidenbaumam atrodoties Tērbatas studentu grupas "Pìpkalonija" centrā, dzejnieka rokās visdrīzāk nonācis kā fotogrāfijas vizualitātē iederīgs rekvizīts un pīpkaloṇu līdera simbolisks amata rīks. Savukārt Kalāčos eksponētais Birutas Leites ekspozīcijas plānā pieteikts kā "Eduarda Veidenbauma darināts no paegḷa. Eduards Veidenbaums to lietojis staigājot, ieliktu aiz muguras elkoņos." ${ }^{21}$ Turpat tālāk Leite norāda uz šā priekšmeta nonākšanu muzejā, proti, to 20. gadsimta 50. gadu sākumā zem klētinas atradis kāds Bernhards Krūklis no Liepas ciema Rozēniem, kurš atradumu 1960. gada rudenī nodevis muzejam. Taču muzeja vēstij tik kārdinošā leǵenda par šā priekšmeta izcelšanos no Veidenbauma rokas, visticamāk, tapusi līdzīgi kā par daudziem citiem Birutas Leites apkārtnes mājās uzietiem un dzejnieka vai viņa dzimtas piederībai pieṇēmuma veidā "identificētiem” priekšmetiem.

Tāpat kā Eduarda Veidenbauma dzejas tekstu nonākšana līdz lasītājam caur daudzo pārrakstītāju rokām neizbēgami nesusi līdzi no pirmteksta gandrīz neiespējami atsijājamo subjektivitātes klātbūtni, līdzīgi arī dzejnieka piemiṇas dokumentēšana un prezentācija muzeja formātā uzkrājusi virkni subjektīvu un par vēlamām pien,emtu patiesību. Nākamās patiesības rodas apmeklētāja personiskā priekšstata un muzejā eksponētā priekšmeta satikšanās brīdī. Šis daudzo patiesību, leǵendu un detektīva cienīgu meklējumu iespēju kopums ir atslēga uz mūsdienīga un aizraujoša dzejnieka stāsta radīšanu Veidenbauma piemiṇas glabātāju rokās.

\section{Musealisation of Veidenbaums}

\section{Iveta Ruskule}

Awareness of Eduards Veidenbaums as a personality unique to Latvian culture begins only after his untimely death in 1892, when a couple of Veidenbaums's poems were first printed in the literary supplement of the newspaper Dienas Lapa, and three years later, in 1896, his first collection of poems Poems (Dzejas) was published.

The musealisation of the poet's heritage began in 1958 with the establishment of the Veidenbaums's Memorial Museum Kalāči. However, the Kalāči house became a destination for individual enthusiasts and organized groups much earlier. After the poet's death, the daily life of the farm continued there, but in the eyes of the Veidenbaums's poetry enthusiasts, the identity of the house had already acquired a different value code.

${ }^{21}$ Cēsu Vēstures un mākslas muzeja filiāles "Eduarda Veidenbauma memoriālā muzeja "Kalāči"” tematiskais ekspozīcijas plāns. Sastādījusi muzeja vadītāja Biruta Leite. [1975. g.], 18. lpp. Eduarda Veidenbauma memoriālā muzeja "Kalāči" arhīvs. 
Nowadays, the most important exhibit is the barn, where the poet stayed in summers to study for his gymnasium course, read, think, and write. Veidenbaums used a washing roller as a writing surface. Significantly, the museum semantics of this utilitarian household tool for ironing laundry is based on Veidenbaums's relationship with this object - visitors perceive it as a poet's desk, not an ancient ethnographic artifact. The barn itself has also been transformed from an outbuilding into a museum exhibit, the interpretation of which only secondarily touches on the ethnographic aspect of the oldest building in the Kalāč household. The barn, together with the laundry roller, is, first and foremost, a place where visitors in awe strive to meet the atmosphere of the poet's creative laboratory.

World War II dispersed the people of the Kalāči household, as well as destroyed the memories and objectified environment concentrated there. The buildings and the possessions left there lost their museum aura and returned to the harsh environment of utilitarian use: the workers of the collective farm named after Veidenbaums were housed there and a kindergarten was set up.

The establishment of the museum in Kalāč in the spring of 1958 became possible thanks to the persistence of Eduards Veidenbaums's niece Biruta Leite, calling on the officials to preserve the memory of the first Latvian revolutionary poet.

Biruta Leite was setting up the museum in a ruined environment that had lost its authentic aura and many museum items. Her museological choices were determined by the obligatory ideological context and her nostalgic desire to restore the lost Kalāči aura. Leite created the exhibition as a subjective memory document according to the "room" principle, serving as an objectified illustration for her, her mother's and contemporaries' memories of the Kalāči environment. Since only the walls and speculations about the authenticity of certain objects had remained there from the poet's lifetime, items of different origins and authenticity were used to create a sense of memoriality of the exhibition the items donated by the family; standard interior items; items made specifically for the exhibition from relatives' memories. However, the riddles of authenticity are still not completely unravelled for the few items that populate the museum through the dialogue between the museum and the public as those used or created by Eduards Veidenbaums himself. A displayed part of the round glasses that have broken in half (preserved by the poet's cousin) and the juniper wooden cane conjure up the visual image of Veidenbaums in the visitors' imagination, which has been invariably reinforced in the public consciousness by the photograph taken in Dorpat. When seeing the cane, the visitor undoubtedly associates it with the accessory seen on the photo. However, a closer look at the exhibited accessory and the one in the photo makes it clear that these are two different items.

The cane in the hands of the poet, as seen in the photo, probably was used as a prop for the visuality of the photograph. In turn, the exhibit is said to be made by Eduards Veidenbaums. In the early 1950s, this item was found under a barn by Bernhards Krūklis from the Rozēni household in Liepa village. 
Just as Eduards Veidenbaums's poetic texts came to the reader through the hands of many editors and brought certain presence of subjectivity that is difficult to separate from the original text, similarly the documenting and presenting the poet's memory in a museum format has accumulated a number of subjective and desirable truths. This combination of many truths, legends and detective-like investigations is the key to creating a modern and fascinating poet's story placed in the hands of the Veidenbaums's keepers.

Keywords: museum, heritage, Kalāči, barn, laundry roll, cane, authenticity, Biruta Leite. 